moeten zijn; dat had wel wat meer aandacht verdiend. Ook had het geen kwaad gekund de lezer wat meer in te lichten over de verschillende debatten die aangaande het onderwerp van dit boek lopende zijn. Nu lijkt het immers alsof Mulder-Bakker zich als enige contemporaine historica afzet tegen haar mannelijke voorgangers.

Voor vorsers die zich vanuit hun eigen onderzoek interesseren in het fenomeen van laatmiddeleeuwse kluizenaarsvrouwen in de steden van de Lage Landen is dit niet de meest aangewezen toegang tot het onderzoek van Anneke Mulder-Bakker. Maar zo heeft zij het ook niet bedoeld: dit is een werk bestemd voor vorsers van wie het onderzoek niet meteen aanleunt bij het hare. Ook verdient het een plaats op de boekenplank van niet-historici.

Steven Vanderputten, Universiteit Gent

Warnar, G., Ruusbroec. Literature and Mysticism in the Fourteenth Century (Brill's studies in intellectual history 150; Leiden, Boston: Brill, 2007, vi + 370 blz., €99,-, ISBN 978900415869 6).

In het eerste deel van zijn inleiding, getiteld 'Contested Wisdom' ('Omstreden wijsheid'; ik zal meestal verwijzen naar de titels/terminologie uit het Nederlandstalige origineel uit 2003) wijst de auteur erop dat Ruusbroec die hedentendage wordt gerekend tot de grootste christelijke mystici - kort na zijn dood bij tijdgenoten niet onomstreden was. Het was met name de Franse theoloog Jean Gerson, die zo zijn twijfels had bij Ruusbroecs Die gheestelike brulocht, dat naar zijn mening te geleerd was om op een geloofwaardige manier als werk van goddelijke inspiratie te kunnen worden beschouwd. Vanuit Ruusbroecs klooster Groenendaal kwam er direct 'tegengas' van onder andere Jan van Schoonhoven, wiens pleidooi echter niet in staat was iets te veranderen an Gersons oordeel. Theologie moest toch als laatste toetssteen kunnen fungeren voor geopenbaarde waarheid; waarvan hij overigens niet ontkende dat deze bestond. Het kort daarna verschenen De origine monasterii Viridisvallis (Over de oorsprong van het klooster Groenendaal) van Henricus Pomerius legt ook de nadruk op Ruusbroecs begenadiging als mysticus.

In deel twee van de inleiding wordt aangegeven dat de historische dimensies van Ruusbroec in de schaduw zijn gebleven van de aandacht voor zijn mystiek. Hij moet als het ware weer 'teruggeplaatst' worden in de historische letterkunde, temidden van de vertegenwoordigers van de veertiende-eeuwse religieuze cultuur, in wier gezelschap hij zijn werken schreef. Warnar realiseert zich dat dat niet eenvoudig is vanwege de schaarse gegevens. Over zijn leven is niet veel bekend, van zijn werken kan er slechts één gedateerd worden. Daarom zal vooral bovengenoemde Pomerius gebruikt worden; zijn tekst is een onmisbare bron, hoewel die uiteraard niet klakkeloos overgenomen moet worden. Er zal dus onderzoek gedaan worden naar de levensomstandigheden van Ruusbroec, de mensen voor wie hij schreef en de omstandigheden waardoor hijzelf werd beïnvloed. 
Zodoende is het niet verwonderlijk dat het in de eerste paragraaf van deze studie, getiteld 'Brussels' gaat over Ruusbroecs afkomst (was hij de zoon van een alleenstaande moeder?), de eerste jaren van zijn leven en zijn eerste geschrift. In tegenstelling tot andere mystici woont Ruusbroec niet van het begin af an in een klooster. In hoofdstuk 2 'The espousals' (De Brulocht) wordt het leven van Ruusbroec geschetst in de tijd dat hij dit niet onomstreden - zie boven - traktaat schreef. Onder middelnederlandse auteurs zijn weinig mensen die een universiteit bezochten, maar dat betekent niet dat deze teksten inferieur waren. Interessant is de bespreking van afbeeldingen van de mysticus aan het begin van hoofdstuk 3. Er is een voorstelling die Ruusbroec twee maal laat zien: onder een boom schrijvend op een wastafeltje, geïnspireerd door de Heilige Geest in de gedaante van een duif, en aan een lessenaar, waar de gecomponeerde tekst kennelijk in het net wordt geschreven. Deze laatste zou overigens ook een secretaris kunnen zijn. Later wordt Ruusbroec alleen nog maar onder een boom getekend. Hieruit zouden we kunnen opmaken dat contemplatie en inspiratie het belangrijkst zijn in Ruusbroecs werken. Of zijn teksten nauwkeurig gestructureerd en uitgewerkt zijn lijkt daarbij van minder gewicht te zijn.

Vanaf hoofdstuk 4 gaat het over de Groenendaalse periode van de mysticus Ruusbroec. Over de omstandigheden van de verhuizing van de kapelaan van de St. Goedele kerk naar het Zoniënwoud is weinig bekend. Het houdt wel in een bekering tot de beginselen van de vita apostolica. Het weten waard is de vermelding dat de Tielse kroniek (ca. 1455) het oudste geschiedkundige werk is waarin Ruusbroec wordt vermeld zonder raadpleging van de Groenendaalse bronnen. In deze tijd schrijft hij onder andere zijn Geestelijke Tabernakel, een exegetisch commentaar op een aantal boeken van Exodus, het spirituele statuut van de nieuwe gemeenschap. Interessant in deze periode zijn ook de bezoeken die Geert Grote bij hem aflegde. Deze is wat huiverig ten aanzien van bepaalde aspecten van Ruusbroecs mystiek. Ruusbroec probeert hem gerust te stellen door te zeggen dat hij alles heeft geschreven met inspiratie van de Heilige Geest. Ondanks zijn bedenkingen vertaalde Geert de Brulocht in het Latijn, waardoor deze voor meer mensen beschikbaar kwam.

De auteur laat in deze studie zien, dat we middeleeuwse schrijvers - maar niet alleen hen - moeten beoordelen in de historische context waarin zij hun werken schreven. Zij kunnen niet los gezien worden van het publiek waarvoor zij schreven, of de achtergrond vanwaar uit zij schreven. Dat blijkt heel duidelijk uit een soort 'voortgang' die hier geschetst wordt in Ruusbroecs oeuvre: dat van de Brusselse kapelaan heeft andere accenten dan dat van de Groenendaalse prior, al blijft de essentie uiteraard dezelfde. Die essentie is terug te vinden in de driedeling zoals die in de Brulocht wordt gemaakt: via het werkende en begerende leven moet men uiteindelijk uitkomen bij het godschouwende leven als hoogste trap. De mooiste passage uit dit werk is dan ook: 'Siet de brudegom comt, gaet ute hem te ontmoete'. Het is goed dat dit boek nu in het Engels is vertaald, zodat een bredere lezerskring er kennis van kan nemen.

Petty Bange, Radboud Universiteit Nijmegen 


\section{Nieuwe Geschiedenis}

Hollaar, H.J., De Rotterdamse spelen van 1561. Een Hollandse toneelcompetitie met politieke lading (Dissertatie Universiteit van Amsterdam 2006, Delft: Eburon, 2006, 240 blz., €24,50, ISBN 905972140 3).

De literaire producten van rederijkerskamers uit de zestiende eeuw zijn de laatste jaren door diverse met name letterkundige onderzoekers bestudeerd als bronnen van informatie over opvattingen omtrent religie en politiek in de Nederlanden in de beginjaren van de Reformatie. Leidende vraag was daarbij steeds in hoeverre toneel en poëzie van rederijkers trekken van voortschrijdende protestantisering en groeiend politieke verzelfstandiging vertonen. Omdat de rederijkerskunst een relatief groot, deels ongeletterd publiek bereikte, wordt ze gezien als een belangrijke graadmeter van maatschappelijke ontwikkelingen. Op basis van dergelijk onderzoek is meer dan eens gesteld dat rederijkerskamers drijvende krachten tijdens de Opstand waren.

Op die reeks onderzoekingen vormt Hollaars De Rotterdamse spelen van 1561 een logisch vervolg. Hollaar onttrekt in deze studie een bijzondere reeks van negen toneelstukken aan de vergetelheid - de enige volledige reeks uit de zestiende eeuw die is overgeleverd. Die negen stukken werden geschreven ter gelegenheid van het jubileum van de Rotterdamse kamer 'De Blauwe Acolye' (de akelei was als bloem het zinnebeeld van nederigheid en liefde). 'De Blauwe Acolye' schreef in juli 1561 een wedstrijd uit, een oproep om toneelstukken te schrijven waarin antwoord werd gegeven op de volgende vraag: 'Wie den meesten troost oijt quam te baten Die schenen te sijn van Godt verlaten'.

Deze vraag is, zo laat Hollaar zien, ambigue van formulering en constructie, en bood gelegenheid tot het insturen van zeer uiteenlopende antwoorden. Door sommige kamers werd één persoon aangewezen als degene aan wie de meeste troost ooit toekwam; andere kamers verwezen groepen gelovigen als degenen die van God verlaten schenen te zijn. Het gebruik van het woord 'troost' gaf enige consternatie, omdat dit woord een centrale plaats innam in de Heidelbergse catechismus, en daarmee in het protestantse jargon thuis leek te horen. En het woord 'schenen' in het tweede deel van de vraagstelling stelde de verhouding tussen schijn en werkelijkheid aan de orde: in hoeverre vroeg Rotterdam om een kritische beschouwing van, en correctie op de beeldvorming die in de recente geschiedenis van de kerk was ontstaan?

In totaal werden negen antwoorden ingestuurd door kamers uit Leiden, Delft, Gouda, Amsterdam en Rijnsburg, en daarmee was de wedstrijd van 'De Blauwe Acolye' aanvankelijk een zuiver Hollandse aangelegenheid. Maar pikant genoeg is de reeks aan ons overgeleverd dankzij de inbreng van Willem Silvius, die 'staatsdrukker' was van Filips II in Antwerpen. Die vond de reeks in 1564 goed genoeg voor publicatie en verspreiding onder een breder, nietHollands publiek. Betekent de bemoeienis van Silvius nu dat de Rotterdamse 